\title{
Evaluation of Activation Energy and Thermodynamic Properties of Enzyme-Catalysed Transesterification Reactions
}

\author{
Ravindra Pogaku ${ }^{1 *}$, Jegannathan Kenthorai $\operatorname{Raman}^{1}$, Gujjula Ravikumar ${ }^{2}$ \\ ${ }^{1}$ School of Engineering and Information Technology, University Malaysia Sabah, Kota Kinabalu, Malaysia \\ ${ }^{2}$ Indian Institute of Technology, Hyderabad, India \\ Email: *dr_ravindra@hotmail.com
}

Received September 16, 2011; revised November 9, 2011; accepted November 20, 2011

\begin{abstract}
In this study, the activation energy and thermodynamic properties of immobilized enzyme catalysed transesterification reactions were evaluated based on the enzyme substrate transition theory. The activation energy for an enzyme catalysed biodiesel production system were found to be $4.25(\mathrm{kcal} / \mathrm{mole})$ for monoglyceride formation, $5.58(\mathrm{kcal} / \mathrm{mole})$ for di- glyceride formation and 5.50 (kcal/mole) for methyl ester formation respectively. The rate constants were found to be $3.2 \times 10^{10}(\mathrm{~L} / \mathrm{mol} \cdot \mathrm{sec})$ monoglyceride, $3.47 \times 10^{9}(\mathrm{~L} / \mathrm{mol} \cdot \mathrm{sec})$ for diglyceride and $3.93 \times 10^{9}(\mathrm{~L} / \mathrm{mol} \cdot \mathrm{sec})$ for methyl ester. Based on the present work and published literatures, the activation energy of enzyme-catalysed transesterification reactions were found to be lower than the chemical-catalysed and non-catalyzed transesterification reactions. The thermodynamic properties of immobilized enzyme-catalysed transesterification reaction were found to be Gibbs free energy $(\Delta \mathrm{G}=-1.02 \mathrm{kcal} / \mathrm{mol})$, enthalpy $(\Delta \mathrm{H}=544 \mathrm{cal} / \mathrm{mol})$ and entropy $(\Delta \mathrm{S}=5.19 \mathrm{cal} / \mathrm{Kmol})$.
\end{abstract}

Keywords: Activation Energy; Thermodynamic Properties

\section{Introduction}

Biodiesel, a recent topic in every country's policy agenda has brought renaissance to the energy sector. There are several reasons for the introduction of biodiesel as an alternative to conventional fossil-based diesel. These include decreasing dependency on foreign energy supply from declining fossil fuel resources; helping to reduce global warming by using renewable biofuels for the transport sector; lowering emissions of particulate matter, sulphur, carbon monoxide and hydrocarbons [1-3]. Transesterification of triglycerides with alcohol or other acyl acceptors in the presence of a chemical catalyst or biocatalyst or non-catalyst leads to the formation of alkyl ester commercially known as biodiesel.

Transesterification of triglycerides with alcohol is carried out in the presence of a chemical catalyst, biocatalyst or non-catalyst. The current industrial biodiesel technology uses chemical catalyst and non-catalyst which leads to pollution problems due to the soap formation and high energy consumption in the transesterification process. For these reasons, enzymatic transesterification using lipase looks attractive and encouraging in biodiesel production leading to minimal wastewater treatments needs,

${ }^{*}$ Corresponding author. easy glycerol recovery and absence of side reactions [4]. Practical use of lipase in pseudo-homogenous reaction systems presents several technical difficulties, such as contamination of the product with residual enzymatic activity and economic costs. In order to overcome this problem, the enzyme is usually used in its immobilized form so that it can be reused several times to reduce the cost, and improve the quality of the product. Rigorous research is being conducted all over the world to implement enzymatic biodiesel production on a large scale [5].

Various kinetic and model equations have been proposed on immobilized lipase transesterification of oils [6-12]. However, there is no work reported on the thermodynamics aspects of immobilized lipase transesterification reactions. Hence, in this paper, an attempt is made to investigate the thermodynamics aspects of palm oil transesterification reactions catalysed by immobilized lipase.

\section{Materials and Methods}

\subsection{Materials}

Burkholderia cepacia lipase (lipase PS) was procured from Amano Enzyme (Nagoya, Japan). א-carrageenan was procured from FMC Biopolymer (USA). Refined palm oil 
was obtained from Lam Soon Edible Oil Sdn. Bhd. (Malaysia). Methanol, n-hexane and iso-propanol (HPLCgrade) were purchased from Fisher Scientific (Pittsburgh, PA). Methyl esters - triglyceride standards - were purchased from Sigma Chemical Co. (St Louis, MO). All other reagents used were of analytical-grade.

\subsection{Transesterification Process Parameters}

Transesterification of palm oil was carried out in a $50 \mathrm{ml}$ screw-capped baffled conical flask. The optimized process parameters were $10 \mathrm{~g}$ palm oil, $3.15 \mathrm{~g}$ methanol (methanol to oil molar ratio of 7), $1 \mathrm{~g}$ water, and $5.25 \mathrm{~g} \mathrm{im-}$ mobilized lipase PS (prepared via encapsulation technique as described in Jegannathan et al., 2009). [13] The operating conditions were; $30^{\circ} \mathrm{C}$ temperature, $450 \mathrm{rpm}$ reactor mixing intensity, and 4320 minutes reaction time. At the end of each reaction time interval, $1 \mathrm{ml}$ of the reaction mixture was centrifuged at $5000 \mathrm{rpm}$ for 5 minutes. The supernatant containing the biodiesel was analyzed using HPLC for the determination of methyl ester content.

\subsection{Biodiesel Sampling and Analysis}

The composition of the reaction mixture samples were determined using the Hitachi 7000 HPLC, equipped with a degasser, a binary pump, a Zorbax Eclipse XDB-C18 capillary column $(4.6 \mathrm{~mm}, 250 \mathrm{~mm}, 5 \mu \mathrm{m})$ and an UV/ VIS detector. The flow rate of a binary solvent mixture (methanol, solvent $A$ and 2-propanol/n-hexane, 5 (v/v):4 (v/v) solvent B) was $1 \mathrm{ml} / \mathrm{min}$ with a linear gradient (fro$\mathrm{m} 100 \% \mathrm{~A}$ to $40 \% \mathrm{~A}+60 \% \mathrm{~B}$ in 30 ). The column temperature was held constant at $40^{\circ} \mathrm{C}$. The components were detected at $205 \mathrm{~nm}$. The fatty acids were identified by comparing retention times of the oil components with those of standards. The samples of the reaction mixture were dissolved into a mixture of 2-propanol/n-hexane, 5 $(\mathrm{v} / \mathrm{v}): 4 \mathrm{v} / \mathrm{v}$. All samples and solvents were filtered through $0.45 \mu \mathrm{m}$ millipore filters.

\subsection{Transesterification Reaction and Activation Energy}

Biodiesel is produced by transesterification of large, branched triglycerides (TG) into smaller, straight-chain molecules of methyl esters. There are three stepwise reactions with intermediate formation of diglycerides (DG) and monoglycerides (MG) resulting in the production of 3 mol of methyl esters (ME) and $1 \mathrm{~mol}$ of glycerol (GL).

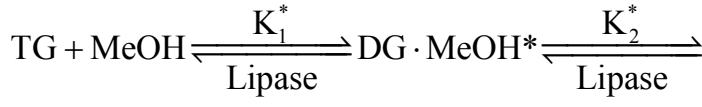

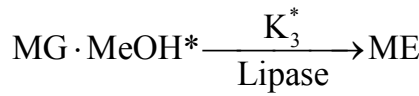

where, $\mathrm{K}_{1}^{*}, \mathrm{~K}_{2}^{*}, \mathrm{~K}_{3}^{*}$ are the rate constants of the consecutive reactions given by,

$$
\begin{aligned}
\mathrm{K}_{1}^{*} & =\frac{\left[\mathrm{DG} \cdot \mathrm{MeOH}^{*}\right]}{[\mathrm{TG}][\mathrm{MeOH}]} ; \mathrm{K}_{2}^{*}=\frac{\left[\mathrm{MG} \cdot \mathrm{MeOH}^{*}\right]}{[\mathrm{TG}][\mathrm{MeOH}]} ; \\
\mathrm{K}_{3}^{*} & =\frac{\left[\mathrm{DG} \cdot \mathrm{MeOH}^{*}\right]}{[\mathrm{TG}][\mathrm{MeOH}]}
\end{aligned}
$$

The energy required to proceed from the reactant state to the transition state, known as the activation energy or energy barrier of the reaction, is the difference in free energy between these two states (Reactant state to product state). The activation energy is represented by the symbol $E_{\mathrm{a}}$. This energy barrier is an important concept to our subsequent discussions on enzyme catalysis. The height of the activation energy barrier can be directly related to the rate of a reaction. The activation energy of the three consecutive reactions can be determined from the rate constants of the reaction using Equation (1).

$$
E_{\mathrm{a}}=-\mathrm{RT} \ln \mathrm{K}^{*}
$$

\subsection{Reaction Rate}

Enzymes accelerate the rates of chemical reactions by stabilizing the transition state of the reaction, hence lowering the activation energy barrier to product formation. In general, a linear decrease in activation energy results in an exponential increase in reaction rate. This is exactly how enzymes function. They accelerate the velocity of chemical reactions by stabilizing the transition state of the reaction, hence lowering the energy barrier that must be overcomed. In the transesterification of palm oil and methanol using immobilized enzyme catalyst, the rate of reaction ( $\mathrm{r}$ ) is given by,

$$
\text { Rate of reaction }(\mathrm{r})=v[\mathrm{TG} \cdot \mathrm{MeOH} *]
$$

where,

$v=\frac{\mathrm{kT}}{\mathrm{h}}=\frac{\mathrm{RT}}{\mathrm{Nh}}$ and $\left[\mathrm{TG} \cdot \mathrm{MeOH}^{*}\right]=\mathrm{K}^{*}[\mathrm{TG}][\mathrm{MeOH}]$

Substituting $v$ and $\left[\mathrm{TG} \cdot \mathrm{MeOH}^{*}\right]$ in equation (2) gives,

$$
\mathrm{r}=\frac{\mathrm{RT}}{\mathrm{Nh}} \mathrm{K} *[\mathrm{TG}][\mathrm{MeOH}]
$$

$\mathrm{r}=\mathrm{k}[\mathrm{TG}][\mathrm{MeOH}]$; where, $\mathrm{k}$ is the second order rate constant, $\mathrm{k}=\frac{\mathrm{RT}}{\mathrm{Nh}} \mathrm{K}$.

\subsection{Gibbs Free Energy, Enthalpy and Entropy}

The Gibbs free energy was determined using the Equation (4),

$$
\Delta \mathrm{G}=\Delta \mathrm{H}-\mathrm{T} \cdot \Delta \mathrm{S}
$$

where, $\Delta \mathrm{H}$ and $\Delta \mathrm{S}$ are the enthalpy and entropy respectively, determined using Equation (5), 


$$
\text { In } \mathrm{K}^{*}=\frac{\Delta \mathrm{H}}{\mathrm{RT}}-\frac{\Delta \mathrm{S}}{\mathrm{R}}
$$

Plot of $\ln \mathrm{K}^{*}$ against $1 / \mathrm{T}$ gave a straight line whose slope was $\frac{\Delta \mathrm{H}}{\mathrm{RT}}$, and the intercept was $\frac{\Delta \mathrm{S}}{\mathrm{R}}$.

\subsection{Disassociation Constant of Immobilized Enzyme}

Immobilized enzymes loose their enzyme activity upon reuse over time. The disassociation constant value shows their deactivation nature given by the Equation (6),

$$
\operatorname{In} \frac{E_{\mathrm{a}}}{E_{\mathrm{a}}(\mathrm{t})}=\frac{-\mathrm{Kd}}{\mathrm{t}}
$$

where, Plot of $\operatorname{In} \frac{E_{\mathrm{a}}}{E_{\mathrm{a}}(\mathrm{t})}$ against $1 / \mathrm{t}$ gave a straight line whose slope was $\mathrm{Kd}$.

\subsection{Turnover Number}

The turnover number is a measure of the efficiency of acatalyst. When using expensive catalysts, however, the tn should be as high as possible so as to reduce the costof the product. Turnover number is defined as the maximum number of molecules of substrate that an enzyme can convert to product per catalytic site per unit of time [14].

\section{Results and DIscussions}

Transesterification reaction of palm oil with methanol at the optimized reaction conditions was carried out in a stirred-tank batch reactor and the results show (Figure 1) that the conversion of triglycerides to methyl esters catalyzed by immobilized PS lipase occurs at three reversible steps with mono- and diglycerol intermediates. From the experimental values, the rate constants and the activation energy of the three consecutive reactions were determined. The rate constants and activation energy values of the enzyme-catalysed (calculated using Equations (1) and (3), chemical-catalysed [15] and non-catalysed palm oil [16] transesterification is shown in Table 1.

The lower activation energy values of enzyme-catalysed palm oil transesterification compared to chemicalcatalysed and non-catalysed palm oil transesterification

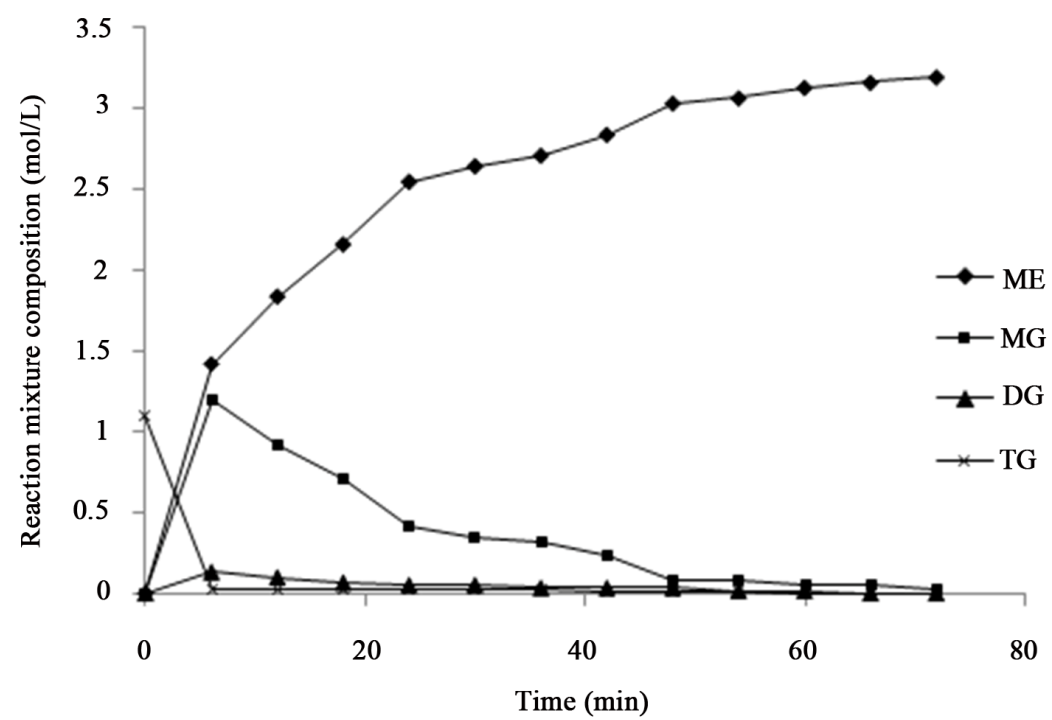

Figure 1. Immobilized lipase catalyzed transesterification of palm oil, subject to $5.25 \mathrm{~g}$ of immobilized lipase, $10 \mathrm{~g}$ of $\mathrm{oil}, 2.5 \mathrm{~g}$ of methanol, $1 \mathrm{~g}$ water and stirring rate of $14.3 \times \mathrm{g} R C F$ at $30^{\circ} \mathrm{C}$.

\begin{tabular}{|c|c|c|c|c|c|c|}
\hline & \multicolumn{2}{|c|}{ Enzyme catalyst $\left(30^{\circ} \mathrm{C}\right)$} & \multicolumn{2}{|c|}{ Chemical catalyst $\left(60^{\circ} \mathrm{C}\right)[15]$} & \multicolumn{2}{|c|}{ Non-catalyst $563^{\circ} \mathrm{C}[16]$} \\
\hline & $E_{\mathrm{a}}(\mathrm{kcal} / \mathrm{mole})$ & $\mathrm{k}(\mathrm{L} / \mathrm{mol} . \mathrm{sec})$ & $E_{\mathrm{a}}(\mathrm{kcal} / \mathrm{mole})$ & $\mathrm{k}(\mathrm{L} / \mathrm{mol} . \mathrm{sec})$ & $E_{\mathrm{a}}(\mathrm{kcal} / \mathrm{mole})$ & $\mathrm{k}(\mathrm{L} / \mathrm{mol} . \mathrm{sec})$ \\
\hline $\mathrm{TG}-\mathrm{DG}$ & 5.58 & $3.47 \times 10^{9}$ & 13.14 & $3.4 \times 10^{10}$ & - & - \\
\hline DG-MG & 4.25 & $3.2 \times 10^{10}$ & 17.40 & $1.5 \times 10^{11}$ & - & - \\
\hline $\mathrm{MG}-\mathrm{ME}$ & 5.50 & $3.93 \times 10^{9}$ & 6.20 & $8.3 \times 10^{10}$ & 10.16 & $9.8 \times 10^{10}$ \\
\hline
\end{tabular}

Table 1. Comparison of activation energy $\left(E_{\mathrm{a}}\right)$ and rate constants $(k)$ of palm oil transesterification reactions. 


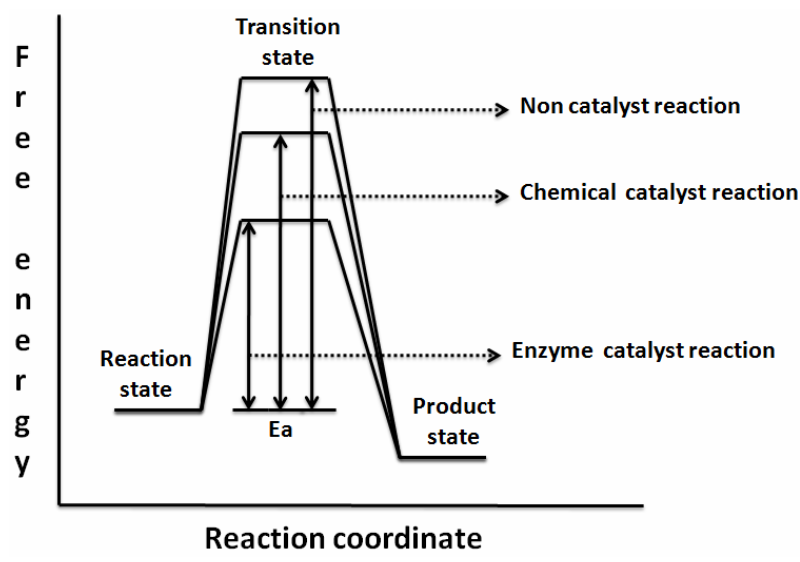

Figure 2. Free energy diagram for the reaction profile of palm oil transesterification reactions.

Table 2. Thermodynamic properties of immobilized lipase enzyme catalyzed biodiesel production.

\begin{tabular}{cc}
\hline Parameters & Values \\
\hline Enthalpy, $\Delta \mathrm{H}$ & $544 \mathrm{cal} / \mathrm{mol}$ \\
Gibbs free energy, $\Delta \mathrm{G}$ & $-1.02 \mathrm{kcal} / \mathrm{mol}$ \\
Entrophy, $\Delta \mathrm{S}$ & $5.19 \mathrm{cal} / \mathrm{Kmol}$ \\
Disassociation constant, Kd & $1 \times 10^{-4} \mathrm{~mole} / \mathrm{sec}$ \\
Turnover number, tn & $308.08 \mathrm{sec}^{-1}$ \\
\hline
\end{tabular}

(Figure 2), thermodynamically demonstrates the feasbility of enzyme-catalysed reaction at lower energy needs. The enzyme-catalysed palm oil transesterification reactions at a lower temperature of $30^{\circ} \mathrm{C}$ attributed to the lower energy needs.

The thermodynamic properties of immobilized enzyme-catalyzed transesterification reactions are given in Table 2. The values of the Gibbs free energy $(\Delta \mathrm{G}=$ $-1.02 \mathrm{kcal} / \mathrm{mol})$, enthalpy $(\Delta \mathrm{H}=544 \mathrm{cal} / \mathrm{mol})$ and entropy $(\Delta \mathrm{S}=5.19 \mathrm{cal} / \mathrm{Kmol})$ denotes a favourable reaction conditions towards forward reactions. In addition, the high turnover number value demonstrates the efficiency of the immobilized lipase catalyst in the transesterification of palm and methanol.

\section{Conclusions}

This study deals with the evaluation of activation energy and rate constants involved in the enzyme-catalysed pa$\mathrm{lm}$ oil transesterification reactions. The activation energy for a enzyme-catalysed biodiesel production system were found to be 4.25 (kcal/mole) for monoglyceride formation, $5.58(\mathrm{kcal} / \mathrm{mole})$ for diglyceride formation and 5.50 (kcal/ mole) for methyl ester formation respectively. The rate constants were found to be $3.2 \times 10^{10}(\mathrm{~L} / \mathrm{mol} \cdot \mathrm{sec})$ monoglyceride, $3.47 \times 10^{9}(\mathrm{~L} / \mathrm{mol} \cdot \mathrm{sec})$ for diglyceride and $3.93 \times 10^{9}(\mathrm{~L} / \mathrm{mol} \cdot \mathrm{sec})$ for methyl ester. Based on the present work and published literatures, the activation energy and reaction rate of enzyme-catalysed transesterification reactions were found to be lower than the chemical-catalysed and non-catalyzed transesterification reactions. Thus, the lower energy needs for enzyme-catalysed transesterification reactions was proven. The thermodynamic properties such as Gibbs free energy, enthalpy, entrophy were demonstrating a favourable reaction conditions towards the forward reactions of product formation. These activation energy and thermodymic property data of enzyme-catalysed palm oil transesterification reactions reported elsewhere could be helpful on an industrial scale in the near future.

\section{REFERENCES}

[1] M. Mittelbach, M. Worgetter, J. Pernkopf and H. Junek, "Diesel Fuel Derived from Vegetable Oils, II: Emission Tests Using Rape Oil Methyl Ester," Energy in Agriculture, Vol. 4, 1985, pp. 207-215. doi:10.1016/0167-5826(85)90017-8

[2] L. C. Meher, D. V. Sagar and S. N. Naik, "Technical Aspects of Biodiesel Production by Transesterification-A Review," Renewable and Sustainable Energy Reviews, Vol. 10, No. 3, 2006, pp. 248-268. doi:10.1016/j.rser.2004.09.002

[3] A. Demirbas, "Progress and Recent Trends in Biofuels," Progress in Energy and Combustion Science, Vol. 33, No. 1, 2007, pp. 1-18. doi:10.1016/j.pecs.2006.06.001

[4] H. Fukuda, A. Kondo and H. J. Noda, "Biodiesel Fuel Production by Transesterification of Oils," Journal of Bioscience and Bioengineering, Vol. 92, No. 5, 2001, pp 405-416. doi:10.1263/jbb.92.405

[5] K. R. Jegannathan, S. Abang, D. Poncelet, E. S. Chan and P. Ravindra, "Production of Biodiesel Using Immobilized Lipase-A Critical Review," Critical Reviews in Biotechnology, Vol. 28, No. 4, 2008, pp. 253-264. doi: $10.1080 / 07388550802428392$

[6] Y. Xu, W. Du and D. Liu, "Study on Acyl Migration in Immobilized Lipozyme," Journal of Molecular Catalysis B: Enzymatic, Vol. 32, No. 5-6, 2005, pp. 241-245. doi:10.1016/j.molcatb.2004.12.013

[7] V. Dossat, D. Combes and A. Marty, "Efficient Lipase Catalysed Production of a Lubricant and Surfactant Formulation Using a Continuous Solvent-Free Process," Enzyme and Microbial Technology, Vol. 30, 2002, pp. 90-94. doi:10.1016/S0141-0229(01)00453-7

[8] S. Al-Zuhair, "Production of Biodiesel: Possibilities and Challenges," Biotechnology Progress, Vol. 21, 2005, pp 1442-1448. doi:10.1021/bp050195k

[9] S. Al-Zuhair, Y. W. Fan and S. J. Lim, "Production of Biodiesel Using Immobilized Lipase-A Critical Review," 
Biotechnology Progress, Vol. 42, 2007, pp. 951- 960.

[10] S. F. A. Halim, A. H. Kamaruddin and W. J. N. Fernando, "Continuous Biosynthesis of Biodiesel from Waste Cooking Palm Oil in a Packed Bed Reactor: Optimization Using Response Surface Methodology (RSM) and Mass Transfer Studies," Bioresource Technology, Vol. 100, 2009, pp. 710-716. doi:10.1016/j.biortech.2008.07.031

[11] B. Cheirsilp and A. H. Kittikun, "Limkatanyu, Impact of Transesterification Mechanisms on the Kinetic Modeling of Biodiesel Production by Immobilized Lipase," Biochemical Engineering Journal, Vol. 35, 2007, pp. 71-80. doi:10.1016/j.bej.2006.12.024

[12] S. F. A Halim and A. H. Kamaruddin, "Continuous Biosynthesis of Biodiesel from Waste Cooking Palm Oil in Packed Bed Reactor," Process Biochemistry, Vol. 43, 2008, pp. 1436-1439. doi:10.1016/j.procbio.2008.08.010

[13] K. R. Jegannathan, E. S. Chan and P. J. Ravindra, "Design an Immobilized Lipase Enzyme for Biodiesel Pro- duction," Journal of Molecular Catalysis B: Enzymatic, Vol. 58, 2009, pp. 78-83. doi:10.1016/j.molcatb.2008.11.009

[14] A. Liese, K. Seelbach and C. Wandrey, "Industrial Biotransformations," Wiley-VCH Verlag GmbH \& Co., Weinheim, 2006

[15] A. F. Chang and Y. A. Liu, "Integrated Process Modeling and Product Design of Biodiesel Manufacturing," Industrial \& Engineering Chemistry Research, Vol. 49, No. 3, 2010, pp. 1197-1213. doi:10.1021/ie9010047

[16] J. Joelianingsih, H. Meada, S. Hagiwara, H. Nabetani, Y. Sagara, T. H. Soerawidjaya, A. H. Tambunan and K. Abdullah, "Biodiesel Fuels from Palm Oil via the Noncatalytic Transesterification in a Bubble Column Reactor at Atmospheric Pressure: A Kinetic Study," Renewable Energy, Vol. 33, No. 7, 2008, pp. 1629-1636. doi:10.1016/j.renene.2007.08.011

\section{Nomenclature}

$E_{\text {a }} \quad$ Activation Energy

$E_{\mathrm{a}}(\mathrm{t}) \quad$ Activation Energy at time $\mathrm{t}$

$\mathrm{R} \quad$ Gas constant

$\mathrm{T} \quad$ Temperature

N Boltzmann constant

H Planck's constant

$\Delta \mathrm{G} \quad$ Gibbs free energy

$\Delta \mathrm{H} \quad$ Enthalpy

$\begin{array}{ll}\Delta \mathrm{S} & \text { Entropy } \\ \mathrm{K}^{*} & \text { Equilibrium constant } \\ \mathrm{K} & \text { Rate constant } \\ \mathrm{R} & \text { Reaction rate } \\ \mathrm{Kd} & \text { Disassociation constant } \\ \mathrm{T} & \text { Time } \\ \mathrm{HPLC} & \text { High-Performance Liquid Chromatography }\end{array}$

